\title{
Synthesis of (+)-Sch 642305 by a Biomimetic Transannular Michael Reaction
}

\author{
Barry B. Snider ${ }^{*}$ and Jingye Zhou \\ Dept of Chemistry MS 015, Brandeis University, Waltham Massachusetts 02454-9110
}

\section{Abstract}

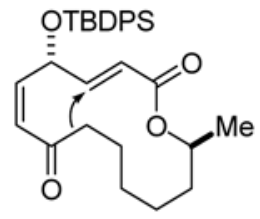

1) $\mathrm{NaH}, \mathrm{THF}$

2) $\mathrm{TFA}, \mathrm{CDCl}_{3}$

3) TBAF, HOAC $\mathrm{THF}$

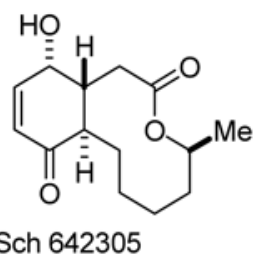

Sch 642305

The synthesis of (+)-Sch 642305 (1) has been completed in 17 steps in 1.6\% overall yield. Transannular Michael reaction of $2 \mathrm{~b}$ with $\mathrm{NaH}$ in THF provided cyclohexenone 23 stereospecifically. Heating 23 in TFA/CDCl 3 provided a 3:1 equilibrium mixture of 23 and 25 , which were hydrolyzed to give (+)-6-epi-Sch 642305 (24) and (+)-Sch 642305 (1), respectively.

In late 2003, Schering-Plough scientists reported the isolation and structure elucidation of the bicyclic macrolide Sch 642305 (1) from Penicillium verrucosum (culture ILF-16214) isolated from soil collected near Tucson, AZ. ${ }^{1}$ The structure was determined spectroscopically and the absolute stereochemistry was assigned by X-ray crystallographic analysis of the $p$ bromobenzoate ester. Macrolide 1 inhibits bacterial DNA primase with an $\mathrm{EC}_{50}$ of $70 \mu \mathrm{M} .^{1}$ In 2005, Merck scientists reported the isolation of $\mathbf{1}$ from the fungus Septofusidium sp. (JP3241) isolated from leaf litter collected in Puerto Rico. ${ }^{2}$ Macrolide 1 inhibits HIV-1 Tat, a regulatory protein required for viral replication, with an $\mathrm{IC}_{50}$ value of $1 \mu \mathrm{M} .^{2}$ Mehta and Shinde recently reported the syntheses of (+)-Sch $642305(\mathbf{1})^{3}$ and (+)-11-epi-Sch $642305^{4}$ using a ring closing ${ }_{5}$ metathesis to elaborate a 10-membered ring lactone onto a highly functionalized cyclohexene.

We thought that Sch 642305 (1) might be biosynthesized by a transannular Michael reaction of the stereochemically simpler hydroxyenone $\mathbf{2 a}$ (see Scheme 1). The close relationship of the macrolides nigrosporolide $(7)^{6}$ and mutolide $(\mathbf{8})^{7}$ to the hypothetical biosynthetic intermediate 2a supports this hypothesis (see Figure 1). If $\mathbf{1}$ is biosynthesized this way, it might also be possible to synthesize it selectively by cyclization of $\mathbf{2 a}$ or a protected derivative such as $\mathbf{2 b}$. The cyclization of $\mathbf{2}$ to $\mathbf{1}$ introduces two new stereocenters so that four isomers are possible. However, related macrolides are often fairly rigid with their conformation controlling the stereochemistry of reactions. ${ }^{8}$ Although there are a few reports of synthetic applications of transannular Michael $^{9}$ and aldol ${ }^{10}$ reactions, the potential of these reactions have not been fully developed.

snider@brandeis.edu.

Supporting Information Available. Full experimental details and copies of ${ }^{1} \mathrm{H}$ and ${ }^{13} \mathrm{C}$ NMR 
Macrolide $\mathbf{2}$ should be readily available by macrolactonization of hydroxyacid $\mathbf{3}$, followed by hydrolysis of the dioxolane. Hydroxyacid $\mathbf{3}$ can be prepared by Lindlar reduction of the alkyne of hydroxy ester $\mathbf{4}$ followed by protecting group modification. Addition of the acetylide anion formed by deprotonation of $\mathbf{6}$ to commercially available aldehyde 5 will provide $\mathbf{4}$ with the complete carbon skeleton of $\mathbf{1}$.

Addition of LiC $\equiv$ CTMS to 7 -octenal $(9){ }^{11}$ in THF at $-40{ }^{\circ} \mathrm{C}$ for $2 \mathrm{~h}$ afforded the propargylic alcohol, which was oxidized with $\mathrm{PCC}$ in $\mathrm{CH}_{2} \mathrm{Cl}_{2}$ for $12 \mathrm{~h}$ to give ynone $\mathbf{1 0}$ in $83 \%$ overall yield (see Scheme 2). Formation of the dioxolane with $\mathrm{HOCH}_{2} \mathrm{CH}_{2} \mathrm{OH}, \mathrm{HC}(\mathrm{OMe})_{3}$, and TsOH in benzene at reflux for $8 \mathrm{~h}$, followed by cleavage of the TMS group with $\mathrm{K}_{2} \mathrm{CO}_{3}$ in $\mathrm{MeOH}$ for $12 \mathrm{~h}$ at $25{ }^{\circ} \mathrm{C}$ afforded $\mathbf{1 1}$ in $89 \%$ yield. Epoxidation of the terminal double bond of $\mathbf{1 1}$ proceeded cleanly with 2 equiv of mCPBA in $\mathrm{CH}_{2} \mathrm{Cl}_{2}$ for $12 \mathrm{~h}$. 2-Methyl-2-butene was added and reaction was continued for $4 \mathrm{~h}$ to consume excess mCPBA, giving racemic $\mathbf{1 2}$ in $99 \%$ yield. Jacobsen kinetic resolution ${ }^{12}$ using $0.01 \mathrm{~mol} \%$ of the oligomeric (salen)Co(III) catalyst ${ }^{13}$ prepared from the $(R, R)$-diamine and 0.5 equiv of $\mathrm{H}_{2} \mathrm{O}$ in $\mathrm{MeCN}$ for $48 \mathrm{~h}$ afforded $46 \%$ of $(R)-12$ in $92.5 \%$ ee as determined by chiral HPLC analysis of the 2-

mercaptobenzothiazole derivative. ${ }^{12 \mathrm{~b}}$ Reduction of the epoxide with $\mathrm{NaBH}_{4}$ in EtOH at reflux for $8 \mathrm{~h}$ afforded $(S)-\mathbf{1 3}$ in $99 \%$ yield. ${ }^{14}$

Initially we had carried out the kinetic resolution of $\mathbf{1 2}$ with $1 \mathrm{~mol} \%$ of the monomeric (salen) $\mathrm{Co}$ (II) catalyst and $4 \mathrm{~mol} \%$ of HOAc, which gave 12 in $43 \%$ yield and $97 \%$ ee. Reduction of this material with $\mathrm{NaBH}_{4}$ in EtOH for $4 \mathrm{~h}$ at $50{ }^{\circ} \mathrm{C}$ afforded a 3:1 mixture of $\mathbf{1 3}$ and the corresponding alkenol resulting from partial reduction of the triple bond. This byproduct was not formed during reduction of racemic $\mathbf{1 2}$. We speculated that cobalt impurities present even in chromatographically purified kinetically resolved $\mathbf{1 2}$ reacted with $\mathrm{NaBH}_{4}$ to form a catalyst that reduced the triple bond. ${ }^{15}$ This was confirmed by reaction of 1-pentadecyne with $1 \mathrm{~mol}$ $\%$ monomeric (salen)Co(II) catalyst and excess $\mathrm{NaBH}_{4}$ in EtOH at $55^{\circ} \mathrm{C}$ to afford $15 \%$ of 1pentadecene. Under these conditions, 1-octyn-3-ol was reduced more rapidly to give mainly 1-octen-3-ol. This side reaction is minimized with the oligomeric (salen)Co(III) catalyst, which can be used at only $0.01 \mathrm{~mol} \%$ loading.

The alcohol of $\mathbf{1 3}$ was protected as the TBS ether with TBSCl and imidazole in DMF for $12 \mathrm{~h}$ at $25^{\circ} \mathrm{C}$ to give 6 in $92 \%$ yield. Deprotonation of 6 with $n$-BuLi in THF at $-40{ }^{\circ} \mathrm{C}$ for $12 \mathrm{~h}$ followed by addition of aldehyde 5 and stirring for $30 \mathrm{~min}$ at $-40{ }^{\circ} \mathrm{C}$ gave $74 \%$ of $\mathbf{1 4}$ as an inseparable 1:1 mixture of diastereomers. Numerous asymmetric additions of acetylide anions to aldehydes have been reported recently including those of Carriera, ${ }^{16} \mathrm{Pu},{ }^{17}$ and Shibasaki. 18 In our hands these procedures worked well on the reported substrates, but not with alkyne $\mathbf{6}$ and aldehyde $\mathbf{5}$. We also oxidized $\mathbf{1 4}$ to give an enynone and investigated CBS-catalyzed asymmetric reduction, ${ }^{19}$ which has been used extensively on enynones. However, the reduction proceeded in only 30-60\% yield with up to $70 \%$ ee. We therefore continued with 14 as a diastereomeric mixture of isomers, with the expectation that they would be readily separated after formation of the macrolide. The rationale for our approach to $\mathbf{1}$ was that the conformation and reactivity of macrolide $\mathbf{2}$ would be controlled by the stereochemistry of the substituents. In a sense, the mixture of diastereomers of $\mathbf{1 4}$ is advantageous because it should allow us to easily investigate the transannular Michael reaction of both $\mathbf{2}$ and its diastereomer.

Hydrogenation of the triple bond of $\mathbf{1 4}$ over $5 \% \mathrm{Pd} /$ poisoned with lead (1 mol\%) in EtOAc containing 0.5 equiv of quinoline under 1 atm $\mathrm{H}_{2}$ for $6 \mathrm{~h}$ gave alkene $\mathbf{1 5}$ in $91 \%$ yield (see Scheme 3). The seven adjacent functionalized carbons in $\mathbf{1 5}$ made progress toward the macrolide challenging. For instance, treatment with TBAF in THF isomerized the allylic alcohol to give ketone 16. Cleavage of the TBS ether with PPTS in EtOH at $50^{\circ} \mathrm{C}$ also cleaved the dioxolane giving a $\gamma$-hydroxy-cis-enone that cyclized and lost water to give furan $\mathbf{1 7}$. Hydrolysis of the TBS ether with pyr/HF gave a diol, which underwent basic hydrolysis with 
$\mathrm{LiOH}$ to give the desired dihydroxy acid. However, attempted macrolactonization under Yamaguchi conditions with $\mathrm{C}_{6} \mathrm{H}_{2} \mathrm{Cl}_{3} \mathrm{COCl}, \mathrm{Et}_{3} \mathrm{~N}$, and DMAP failed; the conjugated doubly allylic alcohol is not stable under the reaction conditions. We hoped that protecting the doubly allylic alcohol with a bulky TBDPS ether would allow the macrolactonization to proceed successfully.

Reaction of 15 with excess TBDPSCl and imidazole in DMF for $12 \mathrm{~h}$ formed the TBDPS ether. $\mathrm{MeOH}$ was added and the solution was stirred for $4 \mathrm{~h}$ resulting in cleavage of the TBS ether to give 18 in $73 \%$ yield (see Scheme 4). Either imidazolium chloride or the $\mathrm{HCl}$ generated by reaction of excess TBDPSCl with $\mathrm{MeOH}$ catalyzed the hydrolysis of the TBS ether without cleaving the dioxolane. Hydrolysis of the ethyl ester with excess $\mathrm{LiOH}$ in 2:1:1 THF/MeOH/ $\mathrm{H}_{2} \mathrm{O}$ for $20 \mathrm{~h}$ at $25^{\circ} \mathrm{C}$ provided carboxylic acid 19 in $90 \%$ yield. Yamaguchi lactonization was effected by slow addition of the mixed anhydride (formed with $\mathrm{C}_{6} \mathrm{H}_{2} \mathrm{Cl}_{3} \mathrm{COCl}$ and $\mathrm{Et}_{3} \mathrm{~N}$ ) to DMAP in toluene at $25^{\circ} \mathrm{C}$ to give $\mathbf{2 0}$ as a difficultly separable mixture of diastereomers in $66 \%$ yield. Heating 20 with catalytic $\mathrm{TsOH}$ in $10: 1$ acetone $/ \mathrm{H}_{2} \mathrm{O}$ at $50{ }^{\circ} \mathrm{C}$ for $16 \mathrm{~h}$ cleaved the dioxolane to give a readily separable mixture of the desired keto lactone $\mathbf{2 b}(44 \%, 88 \%$ from the desired diastereomer of $\mathbf{2 0})$, the diastereomeric ketone lactone $\mathbf{2 1}(6 \%, 12 \%$ from the undesired diastereomer of $\mathbf{2 0}$ ) and the isomerized lactone $\mathbf{2 2}$ (18\%). The stereochemistry of $\mathbf{2 b}$ was assigned by its eventual conversion to $\mathbf{1}$. The stereochemistry of the enol ether double bond of $\mathbf{2 2}$ was established by an NOE between the alkene and phenyl protons.

Pure macrolide 21 is readily isomerized to 22 by TsOH in acetone $/ \mathrm{H}_{2} \mathrm{O}$ at $50{ }^{\circ} \mathrm{C}$, while the desired isomer $\mathbf{2 b}$ is stable. The stereochemistry of the OTBDPS group has a profound effect on the stability of $\mathbf{2 b}$ and $\mathbf{2 1}$. Enol formation from $\mathbf{2 1}$ is more rapid, suggesting that conformers in which the doubly allylic hydrogen is properly aligned with the enone double bond are more accessible for $\mathbf{2 1}$ than for $\mathbf{2 b}$.

Treatment of $\mathbf{2 b}$ with 1.2 equiv of $\mathrm{NaH}$ in THF at $0^{\circ} \mathrm{C}$ for $30 \mathrm{~min}$ afforded the transannular Michael adduct $\mathbf{2 3}$ as a single isomer in $80 \%$ yield (See Scheme 5). Deprotection of $\mathbf{2 3}$ with 1:1 TBAF/HOAc ${ }^{3}$ in THF for $3 \mathrm{~h}$ at $25^{\circ} \mathrm{C}$ provided (+)-6-epi-Sch 642305 (24) in $90 \%$ yield. The cis stereochemistry of $\mathbf{2 4}$ was tentatively assigned based on the $3.2 \mathrm{~Hz}$ coupling constant between $\mathrm{H}_{5}$ and $\mathrm{H}_{6}$. An NOE between $\mathrm{H}_{4}$ and $\mathrm{H}_{6}$ completed the assignment of the cyclohexene stereochemistry. An NOE between $\mathrm{H}_{11}$ and the $\mathrm{H}_{7}$ that is anti-periplanar to $\mathrm{H}_{6}$ suggested that the relative stereochemistry at $\mathrm{C}_{4}, \mathrm{C}_{5}$, and $\mathrm{C}_{11}$ is the same as in Sch 642305 (1). Cyclization of $\mathbf{2 b}$ under a variety of other basic conditions gave predominantly $\mathbf{2 3}$ in lower yields.

Attempted formation of the silyl enol ether from $\mathbf{2 b}$ led mainly to $\mathbf{2 2}$. Hydrolysis of $\mathbf{2 b}$ with $\mathrm{HF} /$ pyr cleaved the silyl ether to give alcohol 2a, which gave complex mixtures on treatment with base.

6-epi-Sch 642305 (24) differs from 1 in the stereochemistry at $\mathrm{C}_{6}$, which is adjacent to a ketone and therefore epimerizable. We were hopeful because MM2 calculations suggested that $\mathbf{1}$ is about $1 \mathrm{kcal} / \mathrm{mol}$ more stable than $\mathbf{2 4}$. Treatment of $\mathbf{2 4}$ under basic conditions resulted in no reaction or decomposition. Treatment of $\mathbf{2 4}$ with $3 \% \mathrm{TFA}$ in $\mathrm{CDCl}_{3}$ for $1 \mathrm{~d}$ at $55^{\circ} \mathrm{C}$ effected dehydration to give only phenol $\mathbf{2 6}$ in $65 \%$ yield. Treatment of $\mathbf{2 4}$ under less acidic conditions with $0.4 \%$ TFA in $\mathrm{CDCl}_{3}$ for $14 \mathrm{~d}$ at $55^{\circ} \mathrm{C}$ gave an inseparable 1.5:1:2 mixture of $\mathbf{2 4}, \mathbf{1}$, and $\mathbf{2 6}$, respectively. Formation of phenol $\mathbf{2 6}$ was minimized by carrying out the isomerization on TBDPS ether $\mathbf{2 3}$. The best results were obtained by microwave irradiation of $\mathbf{2 3}$ in $1.5 \%$ TFA in $\mathrm{CDCl}_{3}$ for $3 \mathrm{~h}$ at $120{ }^{\circ} \mathrm{C}$, which gave a readily separable $1: 3$ mixture of $\mathbf{2 5}$ (23\% isolated, $58 \%$ based on recovered $\mathbf{2 3}$ ) and $\mathbf{2 3}$ (60\% isolated) containing only a trace of phenol $\mathbf{2 6}$. Similar mixtures are obtained starting with $\mathbf{2 5}$ indicating that this is an equilibrium mixture. ${ }^{20}$ The spectral data of $\mathbf{2 5}$ are identical to those reported by Mehta. ${ }^{3}$ Hydrolysis of the TBDPS ether of 25 with TBAF/HOAc ${ }^{3}$ in THF afforded (+)-Sch 642305 (1) in $86 \%$ yield with ${ }^{1} \mathrm{H}$ and ${ }^{13} \mathrm{C}$ NMR spectral data identical to those previously reported. 1,3 
The carbons at $\delta 18.5,22.6,23.0$, and 23.2 are broadened in the ${ }^{13} \mathrm{C}$ NMR spectrum of $\mathbf{2 4}$ and one absorbs as a poorly defined broad peak from $\delta 29.6-30.8$ suggesting that a conformational equilibrium is slow on the NMR time scale. This was confirmed by a ${ }^{13} \mathrm{C}$ NMR spectrum of 24 at $50{ }^{\circ} \mathrm{C}$ that showed sharp peaks. This broadening is similar, but less pronounced, in the ${ }^{13} \mathrm{C}$ NMR spectrum of $\mathbf{1}$ at $25^{\circ} \mathrm{C}$.

In conclusion, we have completed the synthesis of (+)-Sch 642305 (1) in 17 steps in 1.6\% overall yield. Transannular Michael reaction of $\mathbf{2 b}$ with NaH in THF afforded cyclohexenone $\mathbf{2 3}$ stereospecifically. TFA catalyzed equilibration provided a 3:1 mixture of $\mathbf{2 3}$ and $\mathbf{2 5}$, which were hydrolyzed to give (+)-6-epi-Sch 642305 (24) and (+)-Sch 642305 (1), respectively.

\section{Supplemental Materials}

Refer to Web version on PubMed Central for supplementary material.

\section{Acknowledgements}

We thank the NIH (GM50151) for generous financial support. We thank Prof. Eric Jacobsen for a sample of the oligomeric (salen)Co(III) catalyst.

\section{References}

1. Chu M, Mierzwa R, Xu L, He L, Terracciano J, Patel M, Gullo V, Black T, Zhao W, Chan TM, McPhail AT. J Nat Prod 2003;66:1527-1530. [PubMed: 14695789]

2. Jayasuriya H, Zink DL, Polishook JD, Bills GF, Dombrowski AW, Genilloud O, Pelaez FF, Herranz L, Quamina D, Lingham RB, Danzeizen R, Graham PL, Tomassini JE, Singh SB. Chem Biodiversity 2005;2:112-122.

3. Mehta G, Shinde HM. Chem Commum 2005:3703-3705.

4. Mehta G, Shinde HM. Tetrahedron Lett 2005;46:6633-6636.

5 . The numbering scheme used in reference 1 is retained for clarity.

6. Harwood JS, Cutler HG, Jacyno JM. Nat Prod Lett 1995;6:181-185.

7. Bode HB, Walker M, Zeeck A. Eur J Org Chem 2000:1451-1456.

8. Kaisalo L, Hase T. Synthesis 2001:1619-1622.

9. (a) Shimizu I, Nakagawa H. Tetrahedron Lett 1992;33:4957-4958. (b) Matsuura T, Yamamura S. Tetrahedron Lett 2000;41:4805-4809.

10. Karim MR, Sampson P. Tetrahedron Lett 1988;29:6897-6900.

11. Prepared in $84 \%$ yield by PCC oxidation of the commercially available alcohol.

12. (a) Tokunaga M, Larrow JF, Kakiuchi F, Jacobsen EN. Science 1997;277:936-938. [PubMed: 9252321] (b) Schaus SE, Brandes BD, Larrow JF, Tokunaga M, Hansen KB, Gould AE, Furrow ME, Jacobsen EN. J Am Chem Soc 2002;124:1307-1315. [PubMed: 11841300] (c) Ready JM, Jacobsen EN. Angew Chem Int Ed 2002;41:1374-1377. (d) Nielsen LPC, Stevenson CP, Blackmond DG, Jacobsen EN. J Am Chem Soc 2004;126:1360-1362. [PubMed: 14759192]

13. White DE, Jacobsen EN. Tetrahedron: Asymmetry 2003;14:3633-3638. Catalyst 2a was used

14. For the preparation of analogous alcohols see: (a) Chow S, Kitching W. Tetrahedron: Asymmetry 2002;13:779-793. (b) Fürstner A, Thiel OR, Kindler N, Bartkowska B. J Org Chem 2000;65:79907995. [PubMed: 11073608] Lower yields of 13 were obtained with $\mathrm{LiBEt}_{3} \mathrm{H}$

15. (a) Chung SK. J Org Chem 1979;44:1014-1016. (b) Heinzman SW, Ganem B. J Am Chem Soc 1982;104:6801-6802. (c) Satyanarayana N, Periasamy M. Tetrahedron Lett 1984;25:2501-2504.

16. (a) Frantz DE, Fässler R, Carreira EM. J Am Chem Soc 2000;122:1806-1807. (b) Boyall D, López F, Sasaki H, Frantz D, Carreira EM. Org Lett 2000;2:4233-4236. [PubMed: 11150207]

17. Pu L. Tetrahedron 2003;59:9873-9886.

18. Takita R, Yakura K, Ohshima T, Shibasaki M. J Am Chem Soc 2005;127:13760-13761. [PubMed: 16201775]

Org Lett. Author manuscript; available in PMC 2008 September 19. 
19. (a) Corey EJ, Helal CJ. Angew Chem Int Ed 1998;37:1986-2012. (b) McDonald FE, Reddy KS, Díaz Y. J Am Chem Soc 2000;122:4304-4309. (c) Garcia J, López M, Romeu J. Synlett 1999:429-431. (d) Yun H, Danishefsky SJ. J Org Chem 2003;68:4519-4522. [PubMed: 12762760] (e) Parker KA, Katsoulis IA. Org Lett 2004;6:1413-1416. [PubMed: 15101755] (f) Garcia J, López M, Romeu J. Tetrahedron: Asymmetry 1999;10:2617-2626.

20. Although MM2 calculations suggested that 25 is about $1 \mathrm{kcal} / \mathrm{mol}$ more stable than 23 , the equilibration studies indicate that it is less stable. This could be due to inaccuracies in the MM2 calculations or entropic effects. 


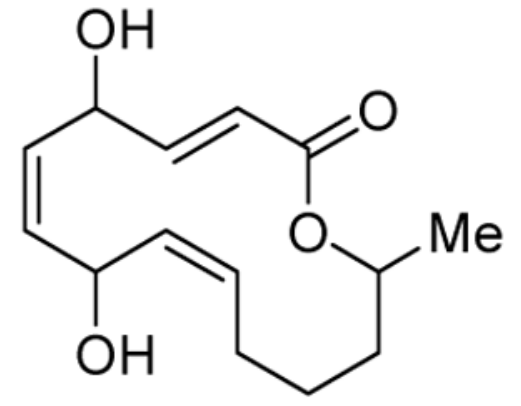

nigrosporolide (7)

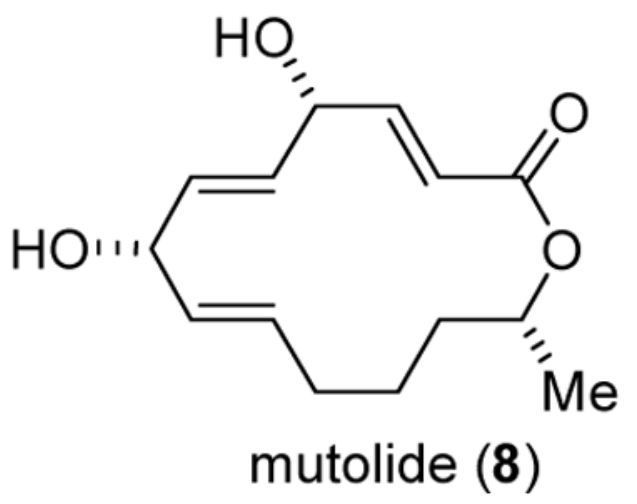

Figure 1.

Structures of nigrosporolide (7) and mutolide (8) 
<smiles>C=CC1C(=O)C=C[C@@H](O)[C@@H]1CC(=O)OC1CCCCC1</smiles>

Sch 642305 (1)<smiles>CCOC(=O)C=CC=O</smiles>
5<smiles>C#CC1(C)OCCO1</smiles>

Scheme 1.

Retrosynthesis of Sch 642305 (1)<smiles>[R]O[C@H]1/C=C\C(=O)CCCCCC(C)O1</smiles>

2a, $\mathrm{R}=\mathrm{H}$ $\mathbf{2 b}, R=$ TBDPS<smiles>C=C[C@H](/C=C/CC1(C/C=C/C(=O)O)OCCO1)C(=O)O</smiles>

3<smiles>[C]=C</smiles><smiles>CCOCC=C[C@@H](O)C#CC1(C)OCCO1</smiles> 


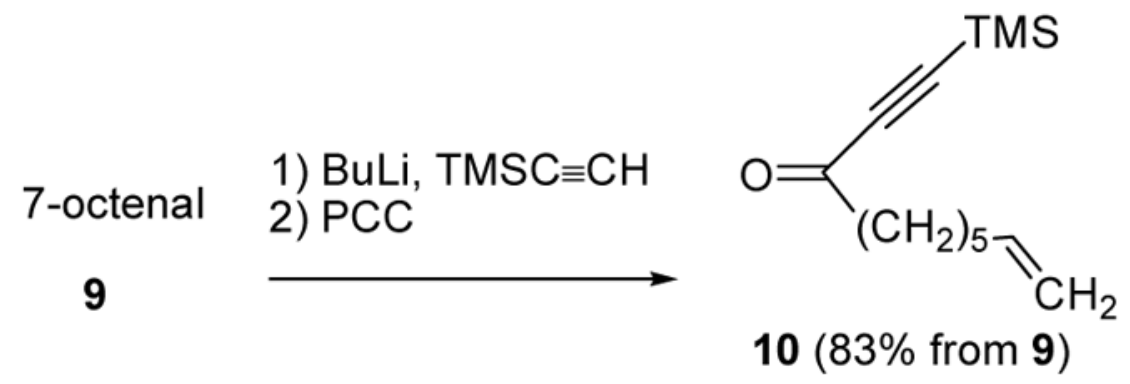

1) $\mathrm{HOCH}_{2} \mathrm{CH}_{2} \mathrm{OH}, \mathrm{HC}(\mathrm{OMe})_{3}$ $\mathrm{TsOH}$, benzene, reflux

2) $\mathrm{K}_{2} \mathrm{CO}_{3}, \mathrm{MeOH}$

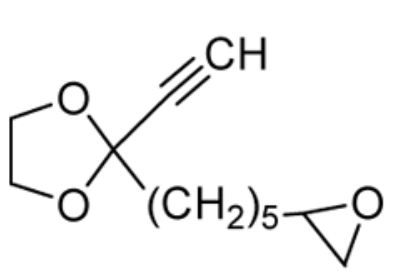

$12(99 \%$, racemic) $12(46 \%, 92.5 \%$ ee $)$
1) 2.2 equiv $\mathrm{mCPBA}$ $\mathrm{CH}_{2} \mathrm{Cl}_{2}, 12 \mathrm{~h}$

2) $0.01 \mathrm{~mol} \%$ oligomeric (salen)Co(III), $\mathrm{MeCN}$<smiles>C#CC1(CCC=C)OCCO1</smiles>
0.55 equiv $\mathrm{H}_{2} \mathrm{O}$

1) excess $\mathrm{NaBH}_{4}$

$\mathrm{EtOH}$, reflux

2) $\mathrm{TBSCl}$, imidazole<smiles>[R]OC(C)[AsH2]</smiles>

13, $R=H(99 \%)$

$6, \mathrm{R}=\mathrm{TBS}(92 \%)$
1.1 equiv $n$-BuLi -78 to $-40{ }^{\circ} \mathrm{C}, 12 \mathrm{~h}$ then 5 $-40^{\circ} \mathrm{C}, 30 \mathrm{~min}$<smiles>CCOCC=C[C@H](O)C#CC1(C)OCCO1</smiles>

$14(74 \%)$

Scheme 2.

Synthesis of $\mathbf{1 4}$ 


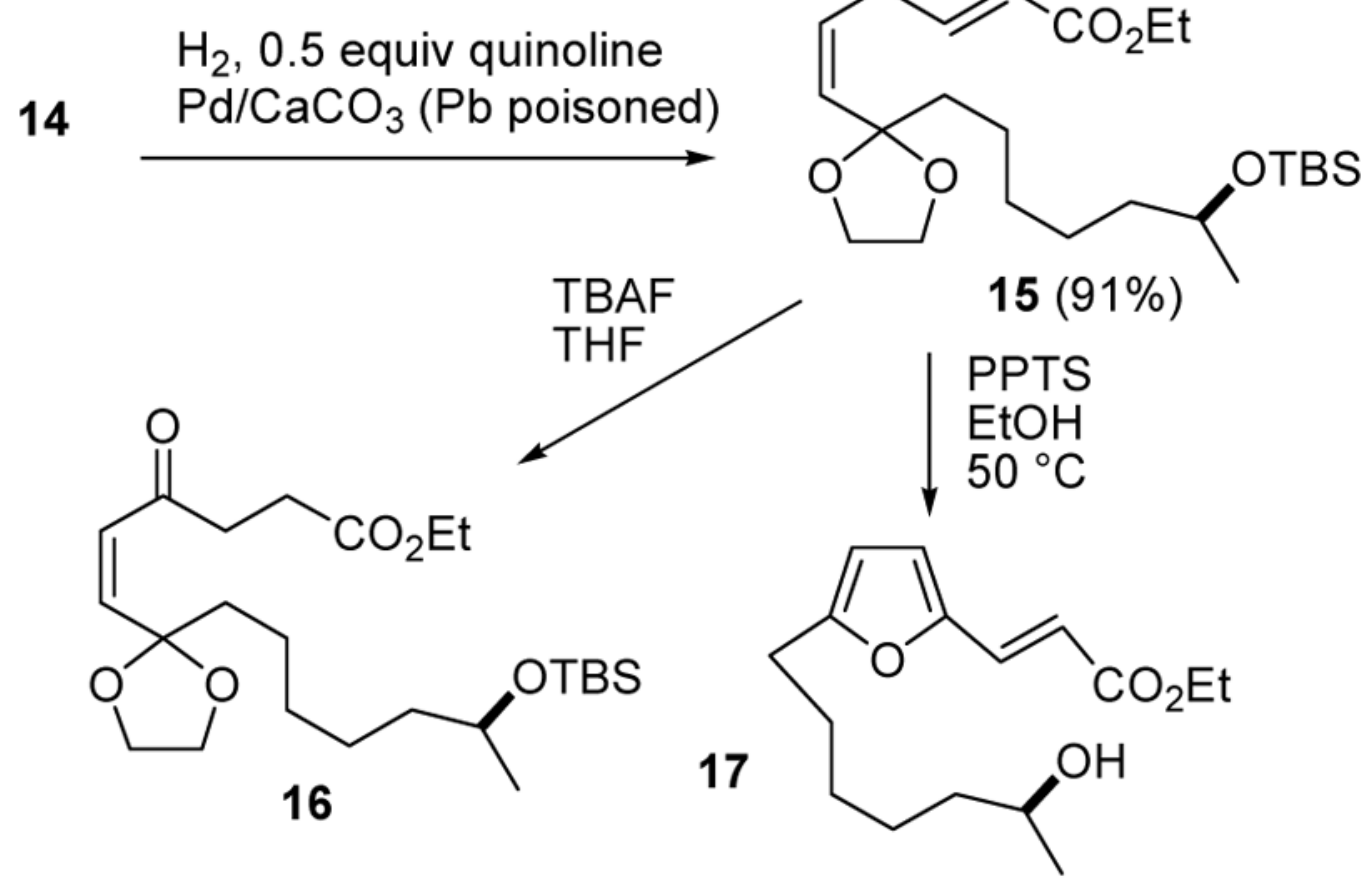

Scheme 3. 
<smiles>CCOC(=O)/C=C/[C@@H](O)/C=C\C1(CCCCC[C@@H](C)O[Sb])OCCO1</smiles>

15
1) TBDPSCI imidazole DMF

then, $\mathrm{MeOH}$

2) $\mathrm{LiOH}$ $\mathrm{THF} / \mathrm{H}_{2} \mathrm{O} / \mathrm{MeOH}$

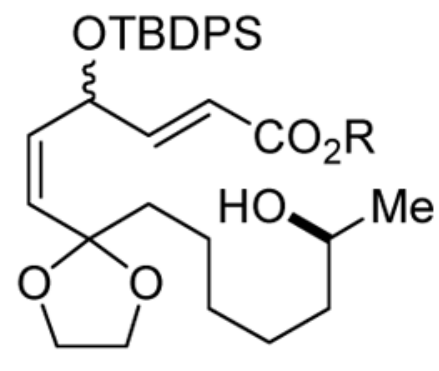

18, $\mathrm{R}=\mathrm{Et}(73 \%)$

$19, \mathrm{R}=\mathrm{H}(90 \%)$

$\mathrm{C}_{6} \mathrm{Cl}_{3} \mathrm{H}_{2} \mathrm{COCl}, \mathrm{Et}_{3} \mathrm{~N}, \mathrm{THF}$ then DMAP, tol<smiles>C[C@@H]1CCCCCC(=O)/C=C\[C@H](/C=C/C(=O)O[PbH2])O1</smiles>

2b (44\%)<smiles>CCCCCC(/C=C\C(=O)OC(C)C)OC(=O)/C=C\C(=O)OC</smiles>

$21(6 \%)$
$\mathrm{TsOH}$, acetone, $\mathrm{H}_{2} \mathrm{O}$ $50{ }^{\circ} \mathrm{C}, 16 \mathrm{~h}$

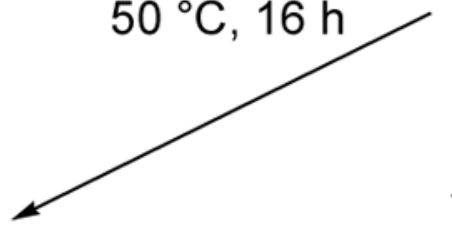

$\mathrm{TsOH}$, acetone, $\mathrm{H}_{2} \mathrm{O}$ $50{ }^{\circ} \mathrm{C}, 16 \mathrm{~h}$

Scheme 4.

Preparation of Keto Lactone 2b 
<smiles>CC(C)O[C@@H](/C=C\C(=O)CCCCCC(C)OC(=O)c1ccccc1)/C=C/C(=O)O</smiles>

1.2 equiv $\mathrm{NaH}$

THF, $0^{\circ} \mathrm{C}, 30 \mathrm{~min}$<smiles>[123I]</smiles><smiles>CC(C)OC(=O)CC1(C)[C@@H](C)CCCC[C@@H]1C</smiles>

6-epi-Sch 642305 (24, 90\%) $3 \%$ TFA, $\mathrm{CDCl}_{3}$ $55^{\circ} \mathrm{C}, 1 \mathrm{~d}$<smiles>CC1CCCCc2c(O)cccc2CC(=O)O1</smiles>

$26(65 \%)$
TBDPSOQ

$23(80 \%)$<smiles>CC1CCCC[C@H]2C(=O)C=C[C@@H](C)[C@H]2CC(=O)O1</smiles>

, HOAC

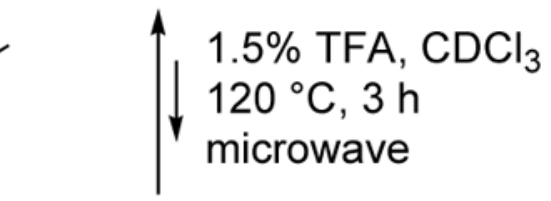

TBDPSO<smiles>C[C@@H]1CCCC[C@H]2C(=O)C=C[C@@H](O)[C@H]2CC1=O</smiles>

$25(23 \%,+62 \%$ recovered 23$)$

TBAF, HOAc<smiles>F[TlH]</smiles><smiles>CC1CCCC[C@H]2C(=O)C=C[C@@H](O)[C@H]2CC1=O</smiles>

Sch 624305 (1, 86\%)

Scheme 5.

Preparation Sch 642305 (1) 